\title{
Interpretasi aksi teo-ecology dan transendentalisme terhadap pelestarian lingkungan
}

\author{
Lukis Alam \\ Institut Teknologi Nasional Yogyakarta \\ Email: lukisalam@itny.ac.id
}

\begin{abstract}
Abstrak
Penelitian ini menghadirkan pembacaan terhadap aspek-aspek transidentalisme agama dalam menghadirkan narasi pelestarian lingkungan. Tentu saja dalam konteks tersebut, penulis mencoba mengilustrasikan dengan konstruksi teoecology berbasiskan wawasan Al-Quran. Oleh karena itu, manusia sebagai subjek, menempati ruang yang luas dalam mengaktualisasikan gagasan ketuhanan dan humanistik di dalam mengelola alam dan lingkungan yang telah Tuhan berikan. Hasil akhir dari penelitian ini memberikan argumen besar terhadap pemaknaan Al-Quran sebagai basis Teo-Ecology lingkungan yang memberikan sumbangsih terdalam agar pelestarian lingkungan senantiasa digalakkan. Selain itu, dalam pelestarian lingkungan diperlukan juga konstruksi etika ekologis memanusiakan lingkungan itu sendiri, sehingga muncul keseimbangan di sana. Yang terakhir, tidak kalah pentingnya memunculkan sikap transendentalisme dalam diri manusia bahwa sebagai wakil Tuhan di Bumi harus memiliki mental mengelola lingkungan dengan baik.
\end{abstract}

Kata Kunci: Lingkungan, Manusia, Teo-Ecology, Transendentalisme, Etika

\section{Abstract}

This research presents a reading of the aspects of religious transidentalism in presenting the narrative of environmental preservation. Certainly in that 
context, the author tries to illustrate with teo-ecology construction based on quranic insights. Therefore, man as a subject, occupies a wide space in realizing the idea of godliness and humanistics in managing the nature and environment that God has given. Result of this study provides a major argument against the meaning of the Quran as the basis of environmental Teo-Ecology which contributes the deepest contribution, so that environmental preservation is always encouraged. In addition, in environmental preservation is necessary also the construction of ecological ethics humanizes the environment itself, so that a balance arises there. Lastly, it is no less important to elicit an attitude of transcendentalism in man that as godss representative on Earth must have mentally managed the environment well.

Keywords: Environment, Human, Teo-Ecology, Transcendentalism, Ethics

\section{Pendahuluan}

Masalah lingkungan telah menjadi isu global, karena menyangkut berbagai sektor dan kepentingan umat manusia. Hal ini terbukti dengan semakin marak isu kerusakan lingkungan. Hal tersebut jika dicermati sebenarnya berakar dari cara pandang dan perilaku manusia terhadap alam lingkungannya.

Manusia seringkali tidak menyadari terjadinya kerusakan lingkungan yang disebabkan oleh perilakunya sendiri. Tuhan telah memberikan salah satu fasilitas yang harus dikelola dengan baik. Namun demikian, bukan berarti manusia bebas menggunakan dan mengeksploitasi sumber daya alam dengan tidak bertanggungjawab. Sebaliknya, manusia seharusnya memanfaatkan secara proporsional, serta menjaga dan melestarikan lingkungan agar dapat terus digunakan.

Islam adalah agama yang komprehensif (syaamil), sempurna (kamil) dan menyempurnakan semua sistem yang lain (mutakamil). Islam mengatur semua sisi kehidupan manusia, sebagaimana diungkapkan dalam QS. al-Maidah [5]: 3.

Agar tetap terpelihara keseimbangan dan kelestarian lingkungan, manusia seyogyanya secara ketat harus menerapkan fungsi dan tugasnya sebagai khalifah guna memberikan jaminan keseimbangan alam yang sudah menjadi tugas. Untuk itu penciptaan Bumi dan seisinya berfungsi sebagai tempat tinggal dan mencari kehidupan bagi manusia dirasa sudah tepat.

Hanya saja, manusia harus memanfaatkannya dengan baik demi kepentingan dan kesejahteraan bersama sesuai perintah Tuhan dalam QS.al- 
Baqarah [2]: 29.

Al-Quran merupakan hudan li al-nas (petunjuk bagi manusia), bukan hudan lillah (petunjuk bagi Allah). Tidak bisa dinafikan lagi, ia tidak hanya menjadi konstruksi utuh atas petunjuk yang Tuhan berikan dalam arti metafisiseskatologis semata (Agwan, 2007), melainkan juga berkaitan dengan masalah dan problematika nyata kehidupan manusia saat ini. Tidak kalah pentingnya juga perhatian Al-Quran bagaimana manusia menyantuni alam dan lingkungan sekitarnya.

Manusia sebagai khalifah bertugas untuk mengelola bumi dan seisinya termasuk tanaman dan hewan dengan sebaik-baiknya. Nadjamuddin (2007) menjelaskan bahwa menurut Al-Quran, manusia sebagai wakil Tuhan di bumi memiliki tanggung jawab vertikal kepada Tuhan dan tanggung jawab horizontal berupa tanggung jawab individu, sosial, dan ekologi.

Islam sebagai agama yang komprehensif telah berupaya mengarahkan manusia untuk senantiasa memperlakukan Bumi dengan baik. Dalam AlQuran sendiri kata Bumi (ardh) disebut sebanyak 485 kali dengan arti dan konteks yang beragam. Di bagian berbeda, komponen-komponen lain di bumi dan lingkungan hidup juga banyak disebutkan dalam Al-Quran dan Al-Hadits (Shihab, 2007).

Manusia sebagai makhluk istimewa di bumi memiliki peran paling utama terhadap proses terjadinya degradasi lingkungan. Manusia sejatinya terus mengembangkan ilmu pengetahuan dan teknologi sebagai sarana untuk mencapai kesejahteraan dan kemakmuran (Komarudin, 2004). Di sisi berbeda, secara implementatif, manusia terkadang tidak dapat mengendalikan laju ilmu pengetahuan dan teknologi, sehingga yang terjadi adalah sebaliknya, manusia dikendalikan oleh ilmu pengetahuan dan teknologi (Pasya, 2006).

Salah satu penyebab hal di atas adalah diabaikannya nilai etika oleh manusia. Etika diperlukan untuk pengkajian sistem nilai-nilai yang telah ada di masyarakat terkait dengan benar atau salah. Terjadinya degradasi lingkungan erat kaitannya dengan kurangnya pemahaman manusia akan etika lingkungan (Callicott, 2009).

Etika lingkungan diperlukan dan dipahami sebagai suatu usaha dan kritik atas etika yang selama ini dianut oleh manusia yang karenanya menjadi petunjuk kuat bagi manusia dalam mengusahakan tata lingkungan yang baik. Selain itu, adanya etika lingkungan bertujuan untuk mengubah pemahaman dan perilaku manusia untuk mengindarkan dari upaya-upaya destruktif terhadap lingkungan itu sendiri sebagai ciptaan Tuhan yang wajib dipelihara. 
Kesadaran itu senantiasa harus didorong kepada manusia agar selalu mengusahakan dalam kehidupannya berperilaku menjaga lingkungan dengan seluruh kompetensi manusiawi yang sudah Tuhan anugerahkan membangun pemahaman yang inklusif, yang seyogyanya manusia merupakan makhluk kolegial dengan sesama manusia, atau pun makhluk lain sesama ciptaan Tuhan, ia harus berkolaborasi menjalin kerjasama sosial.

Tuhan telah menetapkan dalam kehidupan ini untuk saling bergentung, saling membutuhkan dan membantu satu dengan lainnya. Oleh karena itu, tidak bisa dianggap keniscayaan bila ada yang menyatakan bahwa manusia adalah pemegang otoritas tunggal dalam kehidupan ini, sedangkan makhluk hidup lain tidak memiliki hal tersebut, sehingga menganggap tidak ada sumbangsih yang bisa dilakukan oleh lainnya (Mujiono, 2001).

Berdasarkan sedikit uraian di atas, tulisan ini menyoroti perspektif sosiohumanisme Al-Quran dalam mendorong manusia untuk mengedepankan perilaku sosial yang merepresentasikan pandangan mereka terhadap lingkungan. Selain itu juga, mengksplorasi gagasan Al-Quran dalam menyampaikan nilai-nilai luhur mengenai pelestarian lingkungan. Sehingga hal itu menjadi perhatian manusia yang memunculkan kesadaran normatif yang seyogyanya dipatuhi dan diimplementasikan manusia sebagai nilai-nilai universal khalifah fil ardh.

\section{Al-Quran Sebagai basis Teo-Ecology Lingkungan}

Menurut fitrahnya, manusia diciptakan dengan kelebihan berupa akal yang membedakannya dengan makhluk lain. Man is an interpreter being, diartikan sebagai manusia adalah makhluk penafsir. Inilah yang kemudian melatarbelakangi manusia selalu melakukan pemahaman dan penafsiran atas fenomena yang terjadi di sekeliling mereka, termasuk penafsiran terhadap teksteks keislaman, seperti Al-Quran.

Al-Quran sebagai sebuah teks yang diturunkan Tuhan kepada Rasulullah SAW menimbulkan problem tersendiri. Persoalan pertama adalah bagaimana menemukan pemahaman yang diterima umat manusia agar sesuai dengan pemahaman yang dikehendaki Tuhan. Problem kedua, bagaimana menjelaskan isi teks keagamaan kepada masyarakat yang hidup di tempat dan dalam kurun waktu yang berbeda (Komaruddin, 1996).

Penafsiran terhadap Al-Quran pertama kali dilakukan oleh Nabi Muhammad SAW sebagai penerima wahyu dari Allah SWT. 
Penafsiran pertama tentang pengungkapannya dalam bahasa Arab. Penafsiran kedua adalah penafsiran atas maksud dari Al-Quran sendiri itu sendiri. Sepeninggal Rasulullah SAW, proses penafsiran terhadap Al-Quran dan Al-Hadits terus berlangsung sampai sekarang. Hal ini disebabkan karena AlQuran yang waktu itu diturunkan di Arab sudah pasti kondisi masyarakatnya berbeda dengan kondisi masyarakat di Indonesia maupun di negara-negara lain (Komaruddin, 1996).

Kebutuhan manusia akan sumber energi terus bertambah seiring dengan bertambahnya populasi manusia di bumi ini. Pembangunan juga terus dilakukan untuk menuhi kebutuhan manusia akan sumber daya namun sayangnya masih banyak pembangunan yang dilakukan tidak berdasarkan prinsip pembangunan berkelanjutan (Keraf, 2010). Terutama pembangunan yang masih mengabaikan prinsip pembangunan berkelanjutan berupa harmonisasi antara aspek ekonomi, ekologi, dan sosial yang merupakan sumber terjadinya degradasi lingkungan (Foltz, 2003).

Degradasi lingkungan justru membuat pembangunan kehilangan tujuannya untuk mensejahterakan kehidupan manusia. Kelangkaan air bersih karena penurunan muka air tanah dan pencemaran sungai oleh limbah industri dan rumah tangga, banjir dan longsor karena deforestasi hutan, dan pemanasan global karena peningkatan efek gas rumah kaca merupakan beberapa contoh dari degradasi lingkungan yang kini sangat erat dengan kehidupan sehari-hari manusia di bumi (Barbour, 2005).

Degradasi lingkungan ini tidak hanya merugikan manusia tetapi juga makhluk hidup lainnya di bumi. Adanya degradasi lingkungan mengambarkan kegagalan manusia dalam mengelola lingkungan. Di lain pihak manusia merupakan mahluk hidup yang istimewa karena dianugerahi akal dan pikiran oleh Tuhan yang disebutkan pada QS. al-Baqarah [2]: 30.

Pada ayat Al-Quran tersebut tersirat bahwa Allah SWT menciptakan manusia sebagai khalifah atau pemimpin di bumi. Manusia sebagai khalifah bertugas untuk mengelola bumi dan seisinya termasuk tanaman dan hewan dengan sebaik-baiknya. Supardi (1996) menjelaskan bahwa menurut Al-Quran, manusia sebagai wakil Tuhan di bumi memiliki tanggungjawab vertikal kepada Tuhan dan tanggungjawab horizontal berupa tanggungjawab individu, sosial, dan ekologi.

Lingkungan hidup merupakan dukungan terhadap kehidupan dan kesejahteraan, bukan saja terhadap manusia, tetapi juga makhluk hidup lain, 
seperti hewan dan tumbuhan. Oleh karena itu, seluruh isi alam diperuntukkan bagi kelangsungan hidup dan kesejahteraan manusia, maka tumbuhan dan hewan yang dapat mendukung kedua hal tersebut harus tetap terjaga ke dalam fungsinya sebagai pendukung kehidupan (Syadili,1992).

Karena lingkungan mempunyai hubungan yang sangat banyak dengan penghuni, banyak interaksi dan korelasinya. Maka perlu dicermati untuk memperoleh gambaran lengkap tentang kerumitan yang terdapat dalam lingkungan hidup, agar pengelolaan lingkungan hidup dapat dilaksanakan setepat mungkin (Arya, 1999)

Pengelolaan lingkungan hidup adalah pemanfaatan dan peningkatan kualitas lingkungan hidup yang diamanahkan kepada manusia, dengan sebab Tuhan telah menciptakan manusia dari bumi (tanah) dan menjadikan manusia sebagai pemakmurnya (Theria, 2005). Amanat Tuhan yang diberikan kepada manusia ialah memakmurkan bumi ini dengan kemakmuran yang mencakup segala bidang, membina peradaban insani yang menyeluruh, mencakup semua segi kehidupan sehingga dapat mewujudkan keadilan di muka bumi tanpa paksaan dan kekerasan, tentunya dengan kesadaran sendiri (Magnis, 1991).

Menyadari manusia dicipta dan dibangun dari komponen-komponen tanah. Oleh karena itu, manusia bertanggungjawab sebagai pembangun, pemelihara dan pemakmur tanah.

Pembangunan itu sendiri adalah bagian penting dari pengelolaan lingkungan yang menjangkau semua lini kehidupan. oleh karenanya harus dipilih prioritas pembangunan yang secara strategi mampu menjangkau sebanyak mungkin segi kehidupan (Magnis, 1991).

Peran kekhalifahan menuntut adanya interaksi antara manusia dengan sesamanya dan dengan alam lingkungannya. Interaksi itu sungguh akan berjalan secara harmonis bila berada atau sesuai dengan petunjuk-petunjuk Tuhan dalam Al-Quran dan Al-Hadits yang senantiasa terus digali kandungannya oleh manusia sambil memperhatikan perkembangan dan situasi lingkungannya (Nadjamuddin, 2007).

Hal tersebut menjadi prinsip pokok atau landasan utama dalam berinteraksi antar sesama manusia dan interaksi antara manusia dengan lingkungan hidupnya, sehingga tercipta kehidupan yang harmonis.

Kerusakan lingkungan yang terjadi telah menyebar di berbagai belahan dunia. Tuhan memberikan potensi yang luar biasa kepada manusia untuk mengelola dunia (Salim, 1993). Namun, terkadang manusia lupa untuk 
mengelola, justru yang terjadi malah merusaknya. Timbulnya kerusakan lingkungan hidup sebagian besar adalah hasil perbuatan manusia. Karena manusia yang diberi tanggungjawab sebagai khalifah di bumi (Harahap, 2007).

Manusia mempunyai daya inisiatif dan kreatif, sedangkan makhlukmakhluk lain tidak memilikinya. Kebudayaan manusia makin lama makin maju sesuai dengan perkembangan dan kemajuan ilmu pengetahuan dan teknologi (Shihab, 2007).

Sejalan dengan kemajuan tersebut, perkembangann persenjataan dan alat perusak lingkungan makin maju juga. Kerusakan lingkungan diperparah dengan banyaknya kendaraan bermotor, dan pabrik-pabrik yang menimbulkan pencemaran udara atau polusi.

Pencemaran tersebut membahayakan keselamatan hidup manusia dan kehidupan sekelilingnya (Salim, 1993). Limbah-limbah pabrik seringkali dibuang sembarangan ke sungai yang akhirnya bermuara ke laut. Demikian pula kapal-kapal tanker yang membawa minyak sering mengalami kebocoran, sehinggga minyak tumpah ke laut. Akibatnya, air sungai dan laut beracun yang menyebabkan mati atau tercemarnya ikan dengan zat beracun.

Krisis lingkungan hidup dalam pandangan Islam merupakan gambaran krisis spiritual paling dalam yang pernah melanda umat manusia akibat pendewaan humanisme yang memutlakkan manusia terhadap alam, sehingga terjadi pemerkosaan alam yang mengatasnamakan hak prioritas manusia (Soedjatmiko, 1991).

Sudah diyakini bahwa Al-Quran telah mendeskripsikan alam sebagai makhluk Tuhan yang pada dasarnya merupakan wujud teofani yang menutupi dan sekaligus mengungkapkan kebesaran Tuhan. Bentuk dan wujud alam merupakan refleksi dialog puitis dari sang Khâliq kepada makhluk-Nya yang mengandung sekian juta makna dan tujuan.

Di satu sisi, alam seolah hanya ingin memiliki dan menyimpan rahasia keilahian Tuhan, namun pada saat yang sama alam tergugah ingin menyibakkan nilai kualitas yang tersimpan bagi kepentingan manusia yang mata batinnya terbutakan oleh anânîyah. Kondisi psikologis ini dicurigai menciptakan kesombongan dan kecenderungan mengumbar nafsu yang mampu menyengsarakan lingkungan hidupnya sendiri (Majid, 2008).

Tinjauan Islam mengenai alam dan lingkungan tidak akan dapat dimengerti sepenuhnya tanpa mengaitkan dengan konsep Islam tentang manusia itu sendiri. Dalam pandangan Islam, manusia selalu dipandang sebagai 
pemelihara alam, namun di jaman modern ini manusia telah berubah menjadi perusak lingkungannya. Islam sendiri memandang manusia dari dua arah, yaitu sebagai wakil Tuhan (QS. al-Baqarah [2]:30) yang cenderung agresif-aktif dan sekaligus hamba Tuhan yang bersifat pasif dalam pengertian yang sebenarnya (QS. al-Al-a'raf [7]: 172).

Apabila konsep ini difahami secara parsial, maka tidak mengherankan jika lahir praktik-praktik anarkisme wakil Tuhan yang hanya menekankan kepentingannya sendiri dalam menguasai alam. Akibatnya, alam mengalami beban eksploitasi yang jauh di luar batas kemampuannya karena tangan-tangan manusia yang tidak lagi menerima kenyataan bahwa dirinya hanya hamba Tuhan yang tidak tahu diri (Al-Qardhawi, 1997). Sehingga muncul anggapan bahwa manusia telah kehilangan esensinya sebagai khalifatullah, sekaligus tidak menganggap dirinya sebagai 'Abd Allâh (hamba Tuhan) lagi.

Di samping konsep aktif-pasif, Islam juga melengkapi pandangannya dengan hak dan tanggung jawab sebagai bagian dari hak asasi manusia (Zayd, 2003). Mengenai masalah ini, Islam bertolakbelakang dengan Barat, karena Islam lebih menekankan unsur "tanggung jawab" mendahului "hak" ketimbang sebaliknya (Aghwan, 1997).

Proporsi yang telah membudaya itu harus dibaca ulang menjadi "tanggung jawab dan hak". Islam mendahulukan tanggung jawab dari pada hak, karena pada hakikatnya manusia tidak memiliki hak apapun yang berada diluar kontrol Allah, baik hak terhadap alam maupun hak atas dirinya sendiri. Hukum ini berlaku karena manusia bukanlah pencipta dirinya sendiri, apalagi alam yang kini menderita akibat ulah manusia (Asmaraman, 1996).

Islam senantiasa berdiri tegak menentang pemutlakan apa yang disebut manusia promothean dan titanik yang memberontak kepada langit. Islam tidak pernah memberikan peluang pemujaan terhadap manusia dengan mengorbankan tanggung jawabnya kepada Tuhan dan ciptaan-Nya (Harahap, 2007).

\section{Nalar Etika Ekologis Yang Humanis}

Tulisan Jorgenson (2003) juga mengingatkan bahwa bahaya terbesar bagi umat manusia di masa depan adalah rusaknya lingkungan hidup yang sangat cepat. Peringatan ini menunjukkan tentang gagalnya upaya konservasi alam dalam mengimbangi cepatnya gerakan eksploitasi sumber daya alam yang didukung oleh berbagai peralatan mutakhir hasil rekayasa ilmu dan teknologi 
modern (Kahuthu, 2006).

Destruksi lingkungan hidup yang membahayakan keselamatan umat manusia tidak hanya dipredeksikan oleh satu-dua ilmuan tersebut. Namun, juga datang dari berbagai ilmuan, seperti Leitmann (2009) yang menyarankan dilakukannya hubungan timbal-balik atau saling menguntungkan antara alam dengan manusia.

Sedangkan Meadows lewat The Limits to Growth (1972) mengecam keserakahan manusia dalam mengeksploitasi alam, dan Bran (2012) melalui tulisannya dalam Sustainable Development Condition for Survival of The Planet mengisyaratkan akan adanya kemungkinan buruk yang bakal menimpa kehidupan umat manusia.

Meski demikian, kenapa dunia modern yang sarat dengan ilmu dan teknologi canggih malah menciptakan bencana bagi kelangsungan hidup manusia dan lingkungannya sendiri?

Masalahnya mungkin terletak pada pijakan yang keliru karena membebaslepaskan ilmu dari nilai agama, bahkan mendasarkan pada konsep taskhîr atau dominion of nature yang memberikan hak khusus kepada manusia untuk bertindak seenaknya terhadap alam. Ini artinya, krisis lingkungan hidup pada dasarnya bermula dari adanya krisis moral, karena mengabaikan tradisi Islam, terutama petunjuk Al-Quran yang berkaitan dengan interaksi manusia dengan alam (Ambary, 1998).

Sejak mengenal peradaban, ribuan bahkan jutaan lalu manusia senantiasa berusaha meningkatkan kualitas hidupnya. Pada abad 19, ketika revolusi industri menguasai sebagian besar benua Eropa, usaha peningkatan kualitas hidup manusia ini sangat terasa gaungnya hingga menyebar ke Amerika. Mereka berlomba menciptakan mesin-mesin baru pengolah bahan mentah menjadi bahan jadi dan setengah jadi. Perlombaan itu juga melanda bidang pertanian dan perkebunan dengan cara membuka lahan-lahan baru di Amerika, Asia, Australia, dan Afrika, melalui mesin-mesin pertanian dan industri yang mampu mempercepat proses produksi (Arnaldez,1971).

Bahan-bahan tambang juga tidak luput menjadi sasaran usaha peningkatan kesejahteraan manusia, sehingga kekayaan alam yang tersimpan dalam perut bumi ikut terkuras. Apalagi dengan penambahan penduduk dunia yang semakin meningkat (Barbier, 1990).

Usaha peningkatan kesejahteraan manusia ini, dari satu sisi memunculkan kemajuan teknologi dan industri yang sangat didambakan oleh setiap bangsa. Di 
sisi lain memberikan dampak kerusakan lingkungan yang menurunkan kualitas dan kesejahteraan hidup manusia itu sendiri. Kekhawatiran manusia atas masalah ini, mulai mengemuka sejak akhir pertengahan abad 20 (Cole, 2003). Hal ini tampak antar lain dengan munculnya pertambahan perbendaharaan kata yang bersifat mendunia, yaitu kata polusi yang menyebabkan terjadinya krisis lingkungan hidup atau environmental crisis (Copeland, 2003).

Munculnya polusi yang mengakibatkan krisis lingkungan hidup menyebabkan para pakar dari berbagai disiplin ilmu mencurahkan perhatian untuk membahas dan meneliti dampak yang diakibatkan oleh kemajuan teknologi dan industri yang telah meracuni udara, air, tanah, dan tumbuhtumbuhan (Kellenberg, 2009).

Polusi ini selanjutnya mempengaruhi fisik manusia melalui makanan dan minuman yang telah tercemar oleh bahan-bahan kimia buatan. Menghadapi masalah krisis lingkungan, secara umum Al-Quran telah mensinyalir bahwa problem itu akan berulang kembali menimpa manusia akibat tindakan dan ulahnya sendiri terhadap alam sebagaimana dipaparkan dalam QS. al-Rûm [30]: 41-4.

Dalam bahasa ekologis, ayat tersebut dapat diartikan bahwa krisis lingkungan hidup akan terjadi bila manusia sudah tidak memperhatikan kelestarian ekologi secara keseluruhan ketika mengeksploitasi alam. Munculnya kerusakan fisik lingkungan hidup ini, pada hakekatnya juga diakibatkan adanya krisis mental manusia. Untuk menghindari bencana yang bakal terjadi, sebenarnya manusia dianjurkan kembali kepada metode Al-Quran dan sekaligus mencermati perubahan ekosistem lingkungan sekitar.

Di ayat tersebut terdapat kata al-fasâd (kerusakan), yang memiliki arti umum dan luas. Dalam pengertian bahasa diartikan "cacat mental dan fisik, kacau-balau, rusak dan binasa”. Sedangkan, secara pengertian istilah, al-fasâd adalah setiap tindakan yang melawan kemapanan dan kemaslahatan (Madjid, 1998).

Para mufasir memberikan arti yang lebih variatif, seperti kemarau panjang, paceklik, tandus, wabah, kematian, mutan (mutasi gen), bencana kebakaran, banjir bandang, kelangkaan pangan dan hewan, stagnasi perdagangan, tidak berkah, tidak ada faedah, bencana alam, terjajah, tertindas, dan masih banyak lagi pengertian yang seirama sesuai dengan perkembangan sejarah perjalanan manusia (Al-Sa'di,1997:284).

Sesuai dengan tekstualisasi ayat, kerusakan lingkungan hidup di bumi 
diakibatkan ulah manusia sendiri. Bencana bisa menjadi peringatan dari Tuhan kepada manusia agar kembali kepada perintah-Nya. Artinya, secara ekologis manusia harus kembali pada metode Al-Quran dalam mengolah kekayaan sehingga tidak terjadi eksploitasi yang merugikan semua pihak.

Sedangkan, ayat kedua menyebutkan kata syirik yang menjadi penyebab utama terjadinya krisis (Al-Zahabi, 1978). Kemusyrikan yang dimaksud di atas adalah tindakan yang mendorong manusia tidak lagi memperhatikan ajaran Al-Quran, tetapi lebih mendewakan kebebasan pikiran, memandang hasil pemikiran individu sebagai sumber dan nilai tertinggi untuk menciptakan kreatifitas individual tanpa merujuk pada konsep-konsep adikodrati (Al-Zahabi, 1978)

Sikap ini dapat dianggap sebagai tindakan yang tidak memperdulikan Tuhan, anti supranaturalistik, terlalu ilmiah, dan humanistik atau dalam bahasa agama disebut syirik, sehingga Tuhan harus menurunkan bencana alam sebagai antitesa keangkuhan manusia. Penafsiran ini tampaknya lebih bersifat non fisik, sesuai penafsiran para mufasir salaf, seperti yang disimpulkan alQurtubi (Al-Sa'di,1997:284-285).

\section{Konstruksi Transendentalisme Manusia Dalam Memperlakukan Lingkungan}

Masalah lingkungan hidup sejatinya merupakan masalah yang kompleks di mana lingkungan lebih banyak bergantung kepada tingkah laku manusia yang semakin lama semakin menurun, baik segi kualitas maupun kuantitas dalam menunjang kehidupan manusia. Ditambah lagi dengan melonjaknya pertumbuhan penduduk yang tidak terkendali dengan baik, maka keadaan lingkungan semakin semrawut (Supardi,1996: 124-131).

Dari kenyataan ini manusia perlu perlahan mengembangkan sikap yang menyayangi alam sekitarnya. Yang perlu diatasi adalah kecenderungan untuk melihat alam sebagai obyek semata, yang hanya dimanfaatkan dan dieksploitasi menuruti nafsu dan kesewenangan manusia. Manusia harus belajar melihat alam sebagai kawan. Keserasian dengan alam bagi manusia, yang diperlukan untuk menghadapi masa depan, bukan persoalan pengetahuan dan konsepsi intelektual semata. Ia tidak lepas dari kemampuan intuitif, ekspresif, dan estetik manusia serta kemampuannya berkomunikasi secara non verbal (Soejatmiko,1990:82-83).

Ketika manusia lahir, saat itu untuk pertama kali ia berkenalan dengan 
dunia luar yang akan menjadi lingkungan bagi dirinya. Ketergantungan manusia terhadap lingkungan memulai kisahnya saat itu. Jika manusia ingin berhenti dan memutus rantai ketergantungannya terhadap lingkungan maka sesungguhnya ia perlu mati. Tetapi sebenarnya hubungan antara manusia dan lingkungannya merupakan keniscayaan yang terjadi dan harus menjadi simbiosis mutulisme. Bahkan ketika lingkungan harus hancur karena manusia, maka di sisi lain manusia tidak bisa memungkiri betapa semakin tertatih hidupnya. Perjalanan hubungan manusia dan alam ini tak ubahnya potret hitam putih. Betapapun indahnya, ironi yang diperlihatkan secara nyata terlalu pahit untuk diingkari (Soejatmiko,1990:61-67).

Salah satu hal yang menarik untuk diketahui adalah bahwa manusia sebagai individu ternyata dapat menjalin hubungan yang harmoni dengan lingkungan sekitar. Meskipun pada dasarnya setiap manusia memiliki kepribadian yang berbeda-beda, namun tanpa disadari kecintaan dan bahkan ketergantungan mereka terhadap lingkungan memposisikan mereka menjadi individu yang berbeda satu dengan yang lain dan secara jelas semakin memantapkan keberadaan perbedaan individu (individual differences) (Soedjatmiko, 1990).

Manusia ditakdirkan Tuhan untuk menempati bumi bersama makhluk lain. Bumi yang ditempati manusia ini disiapkan Tuhan mempunyai kemampuan untuk dapat menyangga kehidupan manusia dan makhluk-makhluk lainn. Akan tetapi karena sunnatullah (hukum Allah), bumi juga mempunyai keterbatasan, sehingga bisa mengalami kerusakan bahkan kehancuran.

Permasalahan kerusakan lingkungan yang terjadi baik dalam lingkup nasional maupun global, jika dicermati sebenarnya berakar dari cara pandang dan perilaku manusia terhadap alam lingkungannya. Perilaku manusia yang kurang atau tidak bertanggungjawab terhadap lingkungannya telah mengakibatkan terjadinya berbagai macam kerusakan lingkungan. Sebagai contoh, pencemaran lingkungan akibat pembuangan limbah atau sampah industri, rumah tangga, dan kegiatan lain yang tidak bertanggung jawab, akhirnya mengancam balik keselamatan dan kehidupan manusia. Penebangan dan atau penggundulan hutan, eksploitasi bahan tambang secara membabi buta juga merupakan perbuatan manusia yang rakus dan tidak bertanggung jawab terhadap lingkungannya. Dalam hal ini perbaikan akhlak masyarakat merupakan sesuatu yang mutlak dan harus diletakkan pada fase pertama dalam upaya penyelamatan dan perbaikan lingkungan (Soedjatmiko, 1990).

Islam merupakan agama yang mengatur semua aspek kehidupan manusia di muka bumi, termasuk juga mengenai bagaimana manusia dalam menjaga 
lingkungannya. Islam memberikan pandangan tersendiri terhadap lingkungan atau alam, karena manusia diciptakan sebagai khalifah di muka bumi, yang harus menjaga dan melestarikan bumi (Nadjamuddin, 2007).

Manusia dan lingkungan memiliki hubungan ketergantungan yang sangat erat. Manusia dalam hidupnya senantiasa berinteraksi dengan lingkungan di mana manusia itu berada. Lingkungan hidup mencakup keadaan alam yang luas. Dalam lingkungan alamnya manusia hidup dalam sebuah ekosistem yakni suatu unit atau satuan fungsional dari makhluk-makhluk hidup dengan lingkungannya.

Dalam ekosistem terdapat komponen abiotik pada umumnya merupakan faktor lingkungan yang mempengaruhi makhluk-makhluk hidup diantaranya: tanah, udara atau gas-gas yang membentuk atmosfer, air, cahaya, suhu atau temperatur, sedangkan komponen biotik diantaranya adalah: produsen, konsumen, dan pengurai. Kehidupan manusia sangat tergantung pada keadaan tumbuh-tumbuhan, binatang, dan lingkungan fisik yang ada disekitarnya (Nadjamuddin, 2007).

Berbagai perspektif digunakan untuk mencari akar persoalan beserta pemecahannya. Agama dan filsafat dipandang punya andil besar dalam membentuk berbagai pandangan tentang penciptaan alam dan peran manusia di dalamnya ( Suseno, 1991:27-31). Pandangan dunia (world view) semacam ini sangat mempengaruhi bagaimana manusia memperlakukan alam.

Di kalangan agamawan, kepedulian akan lingkungan dianggap baru muncul pada dekade 1970-an sebagai akibat dari tumbuhnya kesadaran umum ekologi tahun 1960-an (Baharuddin, 2003:281). Di dalamnya ditegaskan bahwa persoalan lingkungan global berakar dari keyakinan agama. Sejak saat itu, perdebatan tentang teologi-ekologi mulai mendominasi. Kebanyakan mengklaim, dengan menunjukkan cara pembacaan "yang sahih" atas kitab suci masing-masing bahwa agama merekalah yang paling ramah lingkungan (Foltz, 2007). Sebetulnya, menurut Agwan, kepedulian semacam itu di kalangan agamawan, khususnya perhatian pada potensi kearifan agama bagi lingkungan, sudah ada sejak abad ke-17 (Agwan,1997: xi).

Kesadaran manusia yang lebih menitikberatkan posisinya sebagai khalifah, akan menyebabkan manusia merasa paling berhak untuk menguasai alam dalam rangka memenuhi segala kebutuhannya. Namun manusia kerap bertindak mengeksploitasi alam melebihi batas kebutuhannya. Tindakan manusia tersebut pada akhirnya menciptakan krisis-krisis global. Seharusnya 
manusia dapat mengaplikasikan segala potensi yang telah dianugerahkan Tuhan kepadanya. Moralitas yang baik akan mewujudkan kebaikan dalam mengatur segala persoalan termasuk dalam lingkungan hidup (Capra, 2004), yang karenanya manusia membutuhkan ilmu pengetahuan dalam pengelolaannya ( Suseno, 1991:14).

Kelangsungan kehidupan di alam ini pun saling terkait yang jika salah satu komponen mengalami gangguan luar biasa maka akan berpengaruh terhadap komponen yang lain.

Dalam perspektif etika lingkungan (etics of environment), komponen terpenting adalah pengawasan manusia. Islam sebagai agama memiliki panduan dalam melindungi, menjaga serta merawat apa yang telah dianugerahkan Allah SWT. Jika situasi lingkungan semakin memburuk maka kehidupan menjadi sia-sia (Wasim, 2005:78).

Ketidakstabilan lingkungan bahkan rusaknya lingkungan tidak terpisah dari pandangan kosmologis tertentu yang kenyataannya telah menumbuhkan sikap eksploitatif terhadap alam. Karena itu, pengembangan etika lingkungan menghendaki adanya perubahan secara fundamental dari pandangan kosmologis yang menumbuhkan sikap eksploitatif terhadap alam kepada pandangan yang menumbuhkan sikap lebih bersahabat dan apresiatif kepada alam (Sudarminta, 2009:2).

Alam bukan hanya benda yang tidak berarti apa-apa selain dimanfaatkan untuk memenuhi kebutuhan manusia. Alam dalam pandangan Islam adalah tanda (ayat) "keberadaan" Allah. Alam memberikan jalan bagi manusia untuk mengetahui keberadaan-Nya (Nadjamuddin, 2007:25).

Sebagai suatu sistem, lingkungan harus tetap terjaga sehingga sistem itu dapat berjalan dengan teratur dan memberikan manfaat bagi seluruh anggota ekosistem. Manusia sebagai mahluk yang sempurna, yang telah diberikan amanah untuk menjadi khalifah memiliki peran penting dalam menciptakan dan menjaga keteraturan lingkungan itu sendiri. Untuk itul, manusia dituntut untuk mengembangkan perilaku yang baik terhadap lingkungan. Berbagai kerusakan lingkungan yang terjadi dewasa ini sesungguhnya berakar dari perilaku yang salah dari manusia dalam menyikapi dan mengelola lingkungan dan sumber dayanya (Masruri, 2014:411-428).

Martabat manusia dan kualitas hidupnya juga tergantung pada lingkungan yang menjadi tempat hidupnya. Sasaran manusia bukan sekedar agar dapat terus hidup; tujuan manusia adalah suatu kondisi kondusif dan berkesinambungan 
di mana semua orang dapat hidup dalam keselarasan dengan sesama makhluk. Dalam keselarasan dengan lingkungannya dan keselarasan dengan Tuhan sebagai sumber segala kehidupan (Salim, 1993:129-130).

Lebih dari itu, gaya hidup manusia modern yang konsumtif, hedonis, dan anti-ekologi tidak saja telah merusak alam dan lingkungan, tetapi juga berefek negatif terhadap aspek kemanusiaan itu sendiri (Salim, 1993:73-80).

Dalam dunia medis, misalnya, tidak hanya terancam dari bahaya wabah dan kelaparan yang saat ini banyak menimpa negara miskin seperti di Afrika, tetapi juga mengancam masyarakat urban yang tinggal di negara-negara kaya melalui penyakit-penyakit kronis seperti serangan jantung, kanker, lupus dan lainnya, sebagai akibat dari gaya hidup modern, polusi dan makanan sintetis (Syadili, 1992).

Dalam dunia industri, persediaan bahan bakar fosil telah berada di ujung tanduk, sementara alternatif utamanya, reaktor nuklir, menyimpan potensi kerusakan yang tak kalah mengerikan. Dari beberapa contoh di atas, dapat dikatakan bahwa hal tersebut terjadi karena prilaku manusia modern yang memandang alam semata-mata fisik dan bernilai ekonomis (Schumacher 1975, 13-22).

Menurut Keraf (2010) munculnya masalah lingkungan hidup adalah masalah moral, persoalan perilaku manusia. Lingkungan hidup bukan sematamata persoalan teknis. Demikian pula, krisis ekologi global yang di alami dewasa ini adalah persoalan moral, krisis moral secara global. Oleh karena itu perlu etika dan moralitas untuk mengatasinya.

Etika sebenarnya sudah melekat dalam diri seseorang sejak lahir (Keraf, 2002). Tetapi akhir-akhir ini etika tidak muncul, walau kebijakan lingkungan sudah ada tetapi degradasi lingkungan juga semakin meningkat. Munculnya kerusakan ini karena etika lingkungan tidak pernah dikedepankan. Kerusakan lingkungan diperparah karena manusia menganut paham materialisme sehingga terjadi krisis ekologi (Syadili, 1992).

Sebagai makhluk hidup, populasi manusia terus berkembang setiap saat. Pada gilirannya perkembangan ini memberi efek negatif terhadap kualitas interaksi dengan mahluk lain. McElroy menyebutkan kebutuhan manusiasebagai salah satu penghuni bumi- terhadap sumberdaya alam menyebabkan banyak kerusakan, antara lain: adalah pemanasan suhu bumi, pencemaran tanah, air dan udara (Tucker, 2001:2). Menguatkan apa yang disampaikan McElroy, menurut Mujiono pelaksanaan ekonomi industri dewasa ini terjebak 
pada kemakmuran materialisme hedonistik dan energi berkelimpahan, namun melupakan keterbatasan sumber daya alam (Mujiono,2001). Dengan kata lain, manusia dan perkembangan industrinya menjadi "perusak" planetnya sendiri sehingga krisis lingkungan terjadi di berbagai belahan bumi.

Menurut Evanof-sebagaimana dikutip oleh Sudarminta (2009)-krisis ekosistem yang terjadi merupakan akibat dari ketidakseimbangan antara diri (self), kepentingan publik (society), dan hak hidup lingkungan(nature).

Dengan demikian dapat dipahami bahwa krisis lingkungan khususnya, dan krisis kemanusiaan pada umumnya, merupakan bagian dari krisis modernitas yang multidimensional. Menurut Fritjof Capra (2002, 11-14; 2004, 19), krisis-krisis tersebut lahir sebagai akibat dari krisis tunggal, yaitu krisis persepsi. Demikian juga Nurcholish (1998: 186) mengatakan bahwa akar segala krisis dewasa ini mestilah krisis dalam moralitas dan spiritualitas, yang "mengalir" dari atas (para pengambil-keputusan) ke bawah (masyarakat umum). Faktanya, mayoritas manusia modern, terlebih para pengambil kebijakan, selalu menggunakan paradigma sekular yang menganggap bahwa alam semesta dan juga manusia hanya terdiri dari unsur-unsur fisik (Madjid, 1998: 123-131). Akibatnya, solusi yang ditawarkan terkait dengan krisis lingkung masih terbatas pada aspek fisik itu sendiri, seperti menanam kembali pohon-pohon yang telah dihancurkan, tetapi, di tempat lain dan pada saat yang sama, hutan-hutan sedang dihancurkan. Inilah yang disebut dengan paradok modernisme.

Untuk mengatasi berbagai krisis multidimensional di atas, para ilmuan telah mengajukan beberapa solusi alternatif melalui beberapa penelitian, seperti yang diabadikan dalam buku berjudul The Limits to Growth yang meneliti batas fundamental pertumbuhan populasi global, agrikultur, energi fosil, industri, polusi, dan keterkaitan di antara kesemuanya (Meadows, 1974: 10).

Penelitian lain adalah essai berjudul The Historical Roots of Our Ecological Crisis yang ditulis oleh Lynn White tentang akar historis krisis lingkungan, yang tak lain adalah paradigma Judeo-Kristian tentang superioritas manusia atas alam dan Tuhan yang transenden dan supranatural (White, 2014).

Dalam Islam terkandung prinsip-prinsip etika lingkungan yang lebih seimbang, integratif, dan holistik dalam memandang relasi manusia-alam. Menurut Ziauddin Sardar prinsip-prinsip ini meliputi konsep tauhid (tawh』d), khillfah (termasuk di dalamnya konsep am】nah dan 'ilm), istishllh (kepentingan umum) dan halal-haram, serta lainnya meliputi keadilan dan moderasi, kesederhanaan, keseimbangan dan harmoni (i'tidll), dan juga konsep istihs $\llbracket n$ 
(kecenderungan untuk berbuat baik) (Sardar 1987, 133-151).

Semua prinsip ekologis di atas, sebagaimana ditekankan Sardar, merupakan landasan paradigma etika lingkungan berdasarkan ajaran Islam (syarl'ah), dan sekaligus mementahkan tudingan White tentang Islam sebagai modus penyelewengan tradisi Judeo-Kristiani, layaknya Marxisme, dan karenanya turut andil dalam "destruksi monoteistis" atas alam, sebagai suatu tuduhan yang tidak relevan dan tidak masuk akal (Sardar, 1987: 235-236).

Dalam pandangan Sayyed Hossein Nasr, paradigma antroposentris yang berdasarkan kepada materialisme dan sekularisme, telah menyebabkan desakralisasi alam di mana alam semata dilihat pada aspek kuantitatif dan nilai instrumentalnya dalam rangka menghasilkan keuntungan ekonomis yang sebesar-besarnya. Solusi terhadap problem tersebut menurut Nasr, semestinya menjadi resakralisasi alam dan sains (scientia sacra), di mana aspek metafisika terkait hakikat alam mesti dihidupkan kembali dan kualitas sakral sekali lagi diatributkan ke alam semesta (Nasr 1989, 14-21).

Tujuan proyek resakralisasi alam ini tak lain dalam rangka mengembalikan sains modern pada akar metafisikanya. Hanya dengan mengakui kesucian dan aspek kualitatif alam, maka alam akan membuka segala keindahan dan rahasianya, dan pada akhirnya relasi harmoni antara manusia dan alam akan terjalin dengan baik (Nasr, 1989: 23-30).

\section{Kesimpulan}

Krisis lingkungan dan bencana alam yang sering melanda dewasa ini berakibat pada timpangnya ekosistem dunia, di samping itu, karena tingkah laku manusia yang seringkali menghiraukan keseimbangan tatanan ekosistem, maka kerusakan lingkungan menjadi hal yang tidak terhindarkan. Melalui penelitian ini, diharapkan ke depan semakin dapat memberikan sumbangan pemikiran terhadap wacana pelestarian lingkungan dari sudut pandang agama.

\section{Daftar Pustaka}

Abdillah, M. (2001). Agama ramah lingkungan perspektif Alquran. Jakarta: Paramadina.

Agwan, R. (1997). Islam and the environment. New Delhi: Institute of Objective Studies.

Al-Qardhawi, Y. (1997). Fiqih peradaban: Sunnah sebagai paradigma ilmu 
pengetahuan, Surabaya: Dunia Ilmu.

Al-Sa'di, D. S.. (1997). Asrar al-kawn fî al-quran. Beirut: Dar al-Harf al-Arabî.

Al-Zahabi, M. H. (1978). Al-Ittijahat al-mun』arifah fi tafsir alquran al-karim, dawafi'uha wa daf'uha. Kairo: Dar al-Iti'am.

Ambary, H. M. (1998). Menemukan peradaban: Jejak arkeologis dan historis Islam Indonesia. Jakarta: Logos Wacana Ilmu.

Arnaldez, R.. (1971). "al-Ins $\llbracket n$ al-K\mil" dalam Encyclopaedia of Islam, new edition, Vol. 3. Leiden: E.J. Brill.

Asmaraman. (1996). Pengantar studi tasawuf .Jakarta: Raja Grafindo Persada.

Barbier, E. B., \& Markandya, A. (1990). The conditions for achieving environmentally sustainable development. European Economic Review, 34, 659-669.

Barbour, I. (2005). Menemukan Tuhan dalam Sains Kontemporer dan Agama. Fransiskus Borgias (terj). Bandung: Mizan.

Bran, F., \& Ioan, I. (2012). Sustainable development condition for survival of the planet, agro-food and rural economy competitiveness in terms of global crisis ProQuets, Economics of Agriculture SI-1 UDK: 502.131.1, 59, 78-85.

Capra, F. (2004). Titik balik peradaban. M. Thoyibi (terj). Yogyakarta: Bentang.

Cole, M. A., \& Elliott, R. J. R. (2003). Determining the trade-environment composition effect: the role of capital, labor and environmental regulations. Journal of Environmental Economics and Management, 46, 363-383.

Copeland, B. R., and Taylor, M. S. (2004). Trade, growth and the environment. Journal of Economic Literature, 42(1), 7-71, DOI: $10.1257 / 002205104773558047$

Foltz, R. C. , F. M. Denny, A. (2003). Baharuddin (eds.), Islam and ecology: A bestowed trust. Harvard: The President and Fellows of Harvard College.

Harahap. (2007). Rahasia alquran: Alam semesta, manusia, malaikat, dan keruntuhan alam. Jogjakarta: Darul Hikmah.

Hidayat, K. (1996). Memahami bahasa agama: Sebuah kajian hermeneutik. Jakarta: Paramadina.

Hidayat, K. (2004). Menafsirkan kehendak Tuhan. Jakarta: Teraju.

Jorgenson, A. K. (2003). Consumption and environmental degradation: A cross 
national analysis of the ecological footprint. Social Problems, 50(3), 374394.

Kahuthu, A. (2006). Economic growth and environmental degradation in a global context. Environment, Development and Sustainability, 8(1), 55-68.

Kellenberg, D. K. (2009). An empirical investigation of the pollution haven effect with strategic environment and trade policy. Journal of International Economics, 78, 242-255

Keraf, S. (2010). Etika Lingkungan Hidup. Jakarta: PT Kompas Media Nusantara.

Leitmann, J. (2009). Investing in a more sustainable indonesia: country environmental analysis. CEA series, East Asia and Pasific Region. Washington DC.

Madjid, N. (1998). Dialog keterbukaan, artikulasi nilai Islam dalam wacana sosial politik kontemporer. Jakarta: Paramadina.

Masruri, U. N. (2014). Pelestarian lingkungan dalam perspektif Sunnah. Jurnal atTaqaddum, 6 (2), 2014. 411-428

Meadows, D. H., Meadows, D. L., Randers, J., \& Behrens III, W. W. (1972). The limits to growth. universe books. New York.

Meadows, D. L. (1974). The limits to growth. London: Pan Books.

Nashr, S. H. (1989). Knowledge and the sacred. New York : State University of New York Press.

Pasya, A. F. (2006). Dimensi sains Alquran: Menggali ilmu pengetahuan dari Alquran .Solo:Tiga Serangkai.

Ramly, N. (2007). Islam ramah lingkungan konsep dan strategi Islam dalam pengelolaan, pemeliharaan, dan penyelamatan lingkungan. Jakarta Grafindo Khazanah Ilmu.

Salim, E. (1993). Pembangunan berwawasan lingkungan. Jakarta: LP3ES.

Schumacher, E.F. (1975). Small is beautiful. New York: First Perennial.

Shihab, Q. (2007). Membumikan alquran: Fungsi dan peran wahyu dalam kehidupan masyarakat. Bandung: Mizan.

Shihab. Q. (2007). Secercah cahaya ilahi: Hidup bersama alquran. Bandung: Mizan Pustaka.

Soedjatmiko. (1990). Dimensi manusia dalam pembangunan. Jakarta: LP3ES.

Sudarminta, J. (2009). Filsafat organisma whitehead dan etika lingkungan hidup, 
Humanika, Kajian IImiah Mata Kuliah Umum, Vol. 20. No. 2. (2020), 83-102

Jakarta: Driyarkara.

Supardi. (1996). Lingkungan hidup dan kelestariannya. Bandung:Alumni.

Suseno, F. M. (1991). Etika dasar: Masalah pokok filsafat moral. Yogyakarta: Kanisius.

Syadili, A. (1992). Quran dan pemeliharaan lingkungan Hidup, lembaga studi filsafat Islam .Yogyakarta : LESFI.

Tucker, M. E, Grim, J. A. (ed.). 2003. Agama, filsafat, Eु lingkungan hidup, P. Hardono Hadi (terj.). Yogyakarta: Kanisius.

Wardana, W. A. (1999). Dampak pencemaran lingkungan. Yogyakarta: Andi Offset.

Wasim, A. T. (2005). Ekologi agama dan studi agama-agama. Yogyakarta: Oasis Publisher.

White, L. (2014). The historical roots of our ecological crisis, http://www.zbi. ee/ ${ }^{\sim}$ kalevi/lwhite.htm.

Zayd, N. H. A. (2003). Alquran, hermeneutik dan kekuasaan,; Kontroversi dan penggugatan hermeneutik Alquran, Cet. I. Bandung: Research for Quranic Studies RQiS. 